UDC 811.11

DOI https://doi.org/10.32838/2663-6069/2020.1-2/32

Pakulova T. $V$.

Dnipropetrovsk State University of Internal Affairs

Nahorna Y. A.

Dnipropetrovsk State University of Internal Affairs

\title{
UNIVERSAL COMPRESSIVE PROCESSES IN ENGLISH
}

The article deals with the consideration and generalization of compression processes in English and defining the criteria for the selection of English abbreviations. Abbreviations and univerbations are qualified as the most active among them. The units that emerged as a result of these processes are defined as verbal implementations of the respective nominathemes. The purpose of the article is to define the boundaries of the concept of abbreviation in English and to analyze one of the types of abbreviations which is active in the English written language. The choice of the theme is due to its relevance, that is the activity of the formation and operation of abbreviations in Indo-European languages. The object of the study was non-lexical abbreviations, characterized by the identity of the values relative to their underlying structures. The subject is the phenomenon of acronym in English. Nominathemes with a word combination dominant have been analyzed. The following conclusions are drawn: the identity of the word / word semantics and the corresponding abbreviation is the reason for considering the relation between phrase / word and the corresponding abbreviation not as word-forming, as stated earlier; there are several classifications of English abbreviations based on the principle of functioning in the language / speech, the principle of abbreviation for the corresponding basic structures etc. There are universal language trends leading to the emergence of abbreviations and univerbs. The perspectives of linguists who have studied the processes of the mentioned sample in different languages have been researched. The conclusions about the peculiarities of the compressive processes, on the one hand, and the peculiarities of nominathemes with the dominant word combination, on the other, in the English-speaking space, are made. Descriptive and comparative methods were applied. Among the tasks we highlight the following: demonstrate approaches to the classification of English abbreviations; demonstrate the lack of just one approach to defining abbreviations in English; offer criteria for distinguishing English-language abbreviations among other abbreviations. Modern approaches to the distribution of English abbreviations have been investigated. The definition of abbreviation on the basis of the relevant definition in the onomasiological aspect has been derived. It is suggested to consider motivation type as one of the main criterion in defining abbreviations. The role of abbreviation in the process of enrichment of the lexical language system has been outlined. Conclusions are made regarding the relevance of the definition of abbreviations.

Key words: abbreviation, univerbation, nominatheme, phrase, compression.

Problem statement. At the present stage of linguistic and speech phenomena study, the analyses of universal compression processes in Indo-European languages, including abbreviations and universals, is quite relevant. These processes are usually studied within the wordforming system of a language. For this reason, the purpose of the article is to analyze and determine the status of the phenomena of abbreviation and universalization in English. There are several reasons for the emergence of universes and abbreviations: compression in speech and in writing is explained by the effect of the law of saving the means of reflection; there is a communicative (stylistic) need to change the name of an existing phenomenon.
Most studies find interpretations of acronyms as a means of word formation that causes the lexicalization of graphical initial contractions (M.V. Panov); as the process of producing abbreviations - "shortened compound words (nouns) formed from the initial sounds, the names of the initial letters, or the parts of the words on which the abbreviation is formed. The abbreviation may include the whole word" [5, p. 7]. This definition was supplemented by such essential features as "a stable pronunciation of the letters (rarely - sounds) and - as a result - the lexicalisation of the graphic abbreviations to which the most commonly used and time-tested abbreviations are subject". And again: "the abbreviation is aimed 
at the formation of shorter than the primary structures of synonymous nominations" [6, p. 33]. Abbreviation is offered to be understood as "the youngest means of word formation, however, rather productive in modern languages, which aims at greater regulation and orderliness" [7, p. 9].

L. A. Bulakhovsky spoke of this "means of wordformation" as a public need for language: while "people need to hurry to work a lot, the pace of language is accelerated to some extent. The tendency to retain power in order to use it most expediently becomes a vital principle, which the language also obeys" [1, p. 33].

Most linguists agree on the derivative nature of the abbreviation, whereby any abbreviation is the result of lexicalization, that is, a separate independent lexical unit. O. O. Selivanov's hypothesis turns out to be the original opinion $[8$, p. 6], which scrutinizes completely different relationships between the base phrase and the abbreviation.

As for universes, scientists almost unanimously referred them to the results of compressive wordformation, and regarded them as a manifestation of the general law of formal and semantic disunity loss, called them suffixal universes and defined them as one of the cases of lexical condensation.

But all researchers agree on the derivative nature of acronym and univerbality, though the identity of the semantics of the phrase and the resultative unit (abbreviation or univerb) that corresponds to it, suggests that the relations between the word combination and the unity identical to wordy are not word-forming, and that is why these relationships do not lead to the emergence of new nominative units: Ask me anything and AMA, By the way and BTW, Just kidding - JK, In case you missed it - ICYMI, I love you - ILY.

Presentation of basic material of the research. Quite often one can hear the opinion that there is the relation of derivation between the original phrase and its condensation, that is external motivation. But if to assume that external motivation is understood as the relation between two nominathemes, the value of one of which (derivative) is formed by the value of the other (generative) but does not coincide with it, we can state: in the above examples, there are no relations of external word-formation motivation between the generic and derivative units. This can be confirmed by the following observations:

1) the meaning of the word in this case is not determined by the meaning of the phrase, but is exactly the same;

2) grammatical changes do not occur with modifications of this type (we observe the grammatical generic - identity of the main word of the original phrase and the corresponding univerb or abbreviation).
That is why we see word-forming, but not external, derivative, but intrinsic motivational relations between a phrase and its verbal equivalent, which can only be observed between the forms of a certain abstract unit.

Linguists have sought to find a single terminological equivalent to the processes and units that result from these processes. For example, V. I. Terkulov and N. V. Dyachok consider each univerb as a univerbalized doublet of the word combination, that is, a word that has arisen as a result of verbal interpretation of the word cluster, has an absolutely identical lexical and grammatical meaning and syntactic function that the word combination has. They define such a univerbalized pair as a nominatheme similar to "phrase + elliptical univerb". The word that came about as a result of univerbalization, along with the word combination, is a doublet of the nominatheme, which includes both of these units. It is the transformation of the phrase to word that should be defined not as derivation and not as lexicalization, which implies the semantic development of the speech realization of the original nominatheme and the destruction of its actual identity, but as a univerbalization characterized not by change, but by the preservation of the semantics of the word combination in the newly formed word. N. V. Dyachok views the univerb as semantically and grammatically identical to a certain word combination, which can be stylistically different from that word combination in terms of colloquiality, slang, or stylistically coincide with it. Such a word as well as the phrase is a doublet of the same nominatheme.

Abbreviations, in their turn, are also interpreted by V. I. Terkulov as a univerbalized equivalent of a word phrase, namely, a word that has emerged from a proper interpretation of a word combination that has (as well as a univerb) the same lexical and grammatical meaning and syntactical function as the word combination. It may stylistically coincide with the phrase or differ from it in features of documentary and formality. Each language unit under study is qualified as a nominatheme such as "phrase + acronym". Each abbreviation is the result of an abbreviation, that is, a composite compression of a word combination.

Linguists have sought to find a single terminological equivalent to the processes and units that result from these processes. For example, V. I. Terkulov and N. V. Dyachok consider each universe as a universal doublet of a word combination, that is, a word that has emerged as a result of verbal interpretation of a word phrase and has exactly the same lexical and grammatical meaning and syntactic function as the word combination. They define such a universal pair as a nominatheme such as 
"phrase + elliptical universe". The word that came about as a result of universalization, along with the phrase, is a doublet of the nominatheme, which includes both of these units. It is the transformation of the phrase to the word that should be defined not as derivation and not as lexicalization, which implies the semantic development of the speech realization of the original nominatheme and the destruction of its actual identity, but as a universalization characterized not by change, but by the preservation of the semantics of word formation in the newly formed unit. N. V. Dyachok views the universe as semantically and grammatically identical to a certain word combination, which can be stylistically different from that phrase in terms of colloquiality, slang, or stylistically coincide with it. Such a word as well as the phrase is a doublet of one nominatheme.

Abbreviations, in their turn, are also interpreted by V. I. Terkulov as universalized equivalents of a word phrase, namely, as a word that arose from a proper interpretation of a word phrase that has (like theuniverse)thesamelexical and grammaticalmeaning and syntactic function as the word combination. It may stylistically coincide with the phrase or differ from it in features of documentation and officialness. Each language unit under study is qualified as a nominatheme such as "phrase + acronym". Each abbreviation is the result of an abbreviation, that is, a composite compression of the phrase.

The defined nominathemes are part of a group of structural variants of dominant-word nominatheme nouns, that is, units semantically identical to the phrase. We define the relation between an acronym or a universe and the corresponding phrase in each of these units as equal relational, provided the semantic identity is implied.

The phenomenon of compression, which is essential in the acronym and universation, turns out to be universal. It is common not only in Slavic, but also in Germanic languages.

One of the main current language trends is the tendency to save language means. Scientists believe that there are deployed and restricted codes as generalized types of speech strategies. These types of speech strategies reflect context-independent and context-related value systems. A contextindependent value system is versatile, open, to some extent, to all ways of displaying meaningful dependencies and connections. The context-bound value system is optional, open to those with a shared contextual memory. "Limited code is based on condensed, restricted characters, expanded code is on articulated characters. Limited code is used at home, in everyday communication, in an educational institution, in various establishments" [3, p. 67-68].
L. V. Kopot believes that descriptive constructions have a certain disadvantage, therefore, attempts are made to adequately and economically convey the content of multiple word combinations that perform a nominative function. Realizing the need for nomination, we transform existing names by compressing them into more structurally elementary definition, seeking to save time, effort and space spent on pronouncing and writing an analytical name [4].

English, like most other modern Indo-European languages, is no exception to the general process of condensation of speech efforts and linguistic means. Its material clearly demonstrates the following structural types of dominant-word-nominatemic types, which appear all semantically and grammatically identical to a particular word-phrase of a unit:

1) idiomatic word-phrase, that is, collocation, which is understood as "lexical-semantic type of word-combination and phraseological combination" [10, p. 97], for example, sweet home, to the best;

2) word-combination with a functional word, for example, go to school, and analytical lexical semantic variants, for example, go to my native school;

3) the univerbalized (univerbal, verbal) equivalent of a phrase, that is, "a word that has arisen as a result of a synthetic modification of a phrase; it appears identical to the phrase in the lexical and grammatical aspect, that is, it demonstrates the identity of the lexical, grammatical meanings and syntactic function" [2, p. 110].

The third of the dominant-word-type noun types mentioned here has its own structuring.

The synthetic realization of the nominative with the dominant of the analytical sample "is created by the ellipse, the reduction of the combination of words to a word, which, by its nature, is its component" [9, p. 135]:

a) an ellipsis in the direction of a dependent word, for example, dining room - dining;

b) an ellipsis in the direction of a main word, for example, electric pot - pot, gas stove - stove;

c) an elliptical univerbation which is divided into two types:

- nominal, for example: identicals - identical twins, mobiles - mobile phones, parallels - parallel lines, preferences - preference shares, derivatives - derivative securities, contact lenses - contacts, superlative forms - superlatives, comparative forms-comparatives, transients - transient processes;

- verbal, for example: stayed overnight overnighted, to give full throttle - to fullthrottle.

2 . The synthetic implementation of the nominative with the dominance of the analytical sample "is created by the composite compression of phrase" $[9$, c. 135]: 
- an abbreviation of different types, for example, Be right back - BRB, Good game - GG, I don't care $I D C$, Best friends forever $-B F F$, smog $<$ smoke + fog; motel $<$ motor + hotel;

- actually formal compression, in the process of which a simple interpretation of such collocation as aword is observed, for example,play ground-playground, brandbil-brand + bil, albeit-all be it, always - all [the] way, onto - on to, never the less > nevertheless;

- compression univerbation, in the process of which compression is accompanied by word imitation, for example, thanks - thank you, gonna going to.

Conclusions. The English-language factual material proves the universality and activity of the compression processes. The most active among them are the univerbational ones - univerbation and acronym. The units formed as a result of these processes are represented by different structural and morphological types. The study of these varieties is the prospect of our further scientific studies.

\section{References:}

1. Булаховський Л. А. Основи мовознавства. Соціальна природа мови. 2-а лекція : Заоч. пед. вуз. Харків, 1928-1929.

2. Дьячок Н. В. Универбация в русском языке: структурно-семантическое и ономасиологическое описание: дис. ... д. филол. наук : 10.02.02. Киев, 2016. 460 (522) с.

3. Карасик В. Язык социального статуса. Социолингвистический аспект. Прагматический аспект. Лингвосемантический аспект. Москва : Гнозис, 2002. 335с.

4. Копоть Л. В. Универбация как явление словообразования с точки зрения социолингвистики. Режим доступу: http://allbest.ru.

5. Лингвистический энциклопедический словарь / гл. ред. В. Н. Ярцева. Москва : Советская энциклопедия, 1990. - $688 \mathrm{c}$.

6. Мацько О. М. Абревіатури як згорнені мовні формули в дипломатичних текстах. Мовознавство. 2000. № 1. С. 31-36.

7. Русский язык и советское общество / под. ред. М. В. Панова. Москва : Наука, 1968.

8. Селіванова О. О. Лінгвістична енциклопедія. Полтава : Довкілля. Київ, 2010. 844 с.

9. Теркулов В. И. Еще раз об основной единице языка. Вісник Луганського національного університету ім. Т.Г. Шевченка. Луганськ, 2006. № 11(106). С. 127-136.

10. Jackson H. Words and their Meaning. London and New York: Longman, 1995. 279 p.

\section{ПакуЛова Т. В., НагорНа Ю. А. УНІВЕРСАЛЬНІ КОМПРЕСИВНІ ПРОЦЕСИ В АНГЛІЙСЬКІЙ МОВІ}

Статтю присвячено розгляду й узагальненню компресивних прочесів в англійській мові та визначенню критеріїв виділення англомовних абревіатур. Кваліфіковано абревіаџію та універбацію як найактивніші з-поміж них. Одинииі, що з'явилися внаслідок ичих прочесів, визначено як вербальні реалізації відповідних номінатем. Метою статті є означення меж поняття абревіатура в англійській мові та аналіз одного з типів абревіатур, що активно функиіонують в англійському писемному мовленні. Вибір теми зумовлено ї актуальністю, що полягає в активності утворення й функиіонування абревіатур в індоєвропейських мовах. Об’єктом дослідження постали нелексикалізовані абревіатури, що характеризуються тотожністю значення відносно ӥхніх базових структур. Предметом-явище абревіації в англійській мові. Класифіковано номінатеми з домінантою-словосполученням. Зроблено такі висновки: тотожність семантики словосполучення / слова й відповідної абревіатури є підставою для того, щэоб вважати відношення між словосполученням / словом і відповідною абревіатурою не словотвірними, як ие стверджувалося раніше; існує декілька класифікацій англійських абревіатур, що базуються на принципі функиіонування в мові / мовленні, на приниипі відношення абревіатур до відповідних базових структур тощо. Зазначено універсальні мовні тендениії, що призводять до виникнення абревіатур та універбів. Проаналізовано точки зору лінгвістів, які досліджували прочеси зазначеного зразка в різних мовах. Зроблено висновки щодо особливостей компресивних процесів, з одного боку, та своєрідності номінатем з домінантоюсловосполученням, з іншого, в англомовному просторі. Було застосовано описовий, порівняльний методи. Серед завдань виділяємо головні: продемонструвати підходи до класифікаиї англійських абревіатур; продемонструвати недостатність лише одного підходу до визначення абревіатур у англійській мові; запропонувати критерії виокремлення англомовних абревіатур серед іниих скорочень. Здійснено аналіз сучасних підходів до розподілу за групами англійських абревіатур. Надано визначення поняття абревіації, на підставі яких виведено релевантну дефініцію в ономасіологічному аспекті. Запропоновано вважсати тип вмотивованості одним з головних критерїв у визначенні абревіатур. Окреслено роль абревіації у процесі збагачення лексичної системи мови. Зроблено висновки стосовно релевантності визначення абревіатур.

Ключові слова: абревіачія, універбачія, номінатема, абревіатура, універб, словосполучення, компресія. 